\title{
Effectiveness of Guided Inquiry-Based on Blended Learning in Improving Critical Thinking Skills
}

\author{
Rita Saekawati, Harun Nasrudin* \\ Chemistry Department, Universitas Negeri Surabaya \\ JL. Ketintang Kecamatan Gayungan, Surabaya, 60231, Indonesia \\ *Corresponding Author.e-mail: harunnasrudin@unesa.ac.id
}

\begin{abstract}
This research aims to examine the effectiveness guided inquiry learning model based on blended learning on reaction rate material to improve students' critical thinking skills. The design in this research is the One Group Pretest and Posttest Design. The subjects in this research were students of SMAN 1 Kalitidu Bojonegoro in class XI IPA 1. The method used to collect data was the test, observation, and student response questionnaires. Data analysis used the percentage, mean, N-Gain, and Paired sample t-test. The results showed that the guided inquiry learning model based on blended learning was carried out well with an average percentage of the implementation of phase 1 was $98 \%$, phase 2 was $93.76 \%$, phase 3 was $100 \%$, phase 4 was $93.75 \%$, phase 5 was $100 \%$. The average score of the $\mathrm{N}$-gain critical thinking skills is 0.73 with the high category. There is a significant difference in the results of critical thinking skills between before and after being given a guided inquiry learning model based on blended learning. The results showed the guided inquiry learning model based on blended learning effectively improving students' critical thinking skills.
\end{abstract}

Keywords: critical thinking, guided inquiry, blended learning, the reaction rate

\section{Efektivitas Inkuiri Terbimbing Berbasis Blended Learning dalam Meningkatkan Keterampilan Berpikir Kritis}

\begin{abstract}
Abstrak
Penelitian ini bertujuan untuk menguji keefektifan model pembelajaran inkuiri terbimbing berbasis blended learning pada materi laju reaksi dalam meningkatkan keterampilan berpikir kritis peserta didik. Design pada penelitian ini adalah One Group Pretest and Posttest Design. Sasaran dalam penelitian ini yaitu peserta didik XI IPA 1 SMA Negeri 1 Kalitidu Bojonegoro. Metode pengumpulan data yang digunakan berupa tes, observasi dan angket respon. Analisis data menggunakan teknik persentase, mean, n-gain, dan uji Paired Sample T-test. Hasil penelitian menunjukkan bahwa model pembelajaran inkuiri terbimbing berbasis blended learning terlaksana dengan baik dengan rata-rata persentase keterlaksanaan fase 1 sebesar 98\%, fase 2 sebesar 93,76\%, fase 3 sebesar 100\%, fase 4 sebesar 93,75\%, fase 5 sebesar $100 \%$. Nilai rata-rata $\mathrm{N}$-gain kemampuan berpikir kritis adalah sebesar 0,73 dengan kategori tinggi. Terdapat perbedaan hasil keterampilan berpikir kritis yang signifikan antara sebelum dan sesudah diberikan model pembelajaran inkuiri terbimbing berbasis blended learning. Hasil penelitian menunjukkan bahwa model pembelajaran inkuiri terbimbing berbasis blended learning efektif untuk meningkatkan keterampilan berpikir kritis peserta didik.
\end{abstract}

Kata Kunci: berpikir kritis, inkuiri terbimbing, blended learning, laju reaksi

How to Cite: Saekawati, R. \& Nasrudin, H. (2021). Effectiveness of guided inquiry-based on blended learning in improving critical thinking skills. Jurnal Penelitian Ilmu Pendidikan, 14(1), 53-68.

doi:https://doi.org/10.21831/jpipfip.v14i1.36947.

Received 25-12-2020; Received in revised from 28-12-2020; Accepted 12-01-2021

This is an open-access article under the CC-BY-SA license. 


\section{INTRODUCTION}

Science and technology are currently experiencing very rapid changes, so it demands the readiness of all parties to adapt to existing conditions. No exception, education has also undergone renewal from time to time. The development of education by implementing the 2013 curriculum is not only emphasizing cognitive aspects but also emphasizing aspects of attitudes and skills so that quality human resources are obtained and can face developments in all fields. The application of the revised edition of 2013 curriculum learning requires students to think at a high level (High Order Thinking). The use of the 2013 curriculum is following the demands of the 21 st century, where the Ministry of Education and Culture of the Republic of Indonesia developed the 2013 Curriculum by adapting three 21 st century education concepts, namely 21st Century Skills, Scientific Approach, and Authentic Assessment (Murti, 2013). The 21st Century Skills concept contains learning and innovation skills which include critical thinking and problem solving, communication and collaboration, and creativity and innovation (Trilling \& Fadel, 2009). Based on the 21st-century national education paradigm, the learning system is designed to emphasize 4C-based competencies, including critical thinking, creativity, collaboration, and communication.

Based on the results of the international survey Trends in Mathematics and Science Study (TIMSS), it shows that Indonesian students are ranked 45 out of 48 countries (TIMSS, 2015). According to the 2012 Program for International Student Assessment (PISA) report, Indonesia was ranked 64 out of 65 participating countries with an average score of 375, while the international average was 500 (OECD, 2013). The most recent result, namely the 2015 PISA report, found that Indonesia was ranked 62 out of 70 countries with an average score of 403 (OECD, 2016). According to the survey results, it is stated that the performance of Indonesian students in science achievement is generally at a low stage, known as low international benchmarks (Kemendikbud, 2016). The low achievement in TIMSS and PISA use questions with high cognitive level characteristics including measuring student's critical thinking skills.

This fact is supported by the pre-research results at High School of one Kalitidu Bojonegoro, the results of the data on students' critical thinking ability in the reaction rate material for the 2020/2021 school year are still low. This is evidenced by the results of the test of critical thinking skills, which are still low with an average percentage of students who can answer questions correctly in the interpretation component as much as $30.87 \%$, the analysis component is $18.52 \%$, the inference component is $38.89 \%$, and the explanation component is $33.33 \%$. Based on these data, it shows that critical thinking skills have not developed optimally, therefore it needs to be improved. This is in line with the opinion of (Saavedra \& Opfer, 2012) that critical thinking skills should be empowered through learning in schools, especially science learning because critical thinking skills are $21^{\text {st }}$ century thinking skills that students must have. Also, it is very important to empower critical thinking skills because they can affect the results of students' cognitive learning (Cano \& Maryinez, 1991).

Critical thinking skills are essential for students to accurately answer various academic tests and provide students with life skills so that they have skills in making decisions. Students who have critical thinking skills usually tend to provide comments to refute ideas with logical analysis, provide comparisons, provide suggestions and criticism, disagree, think broadly, or think conically and have skills in solving problems (Amri, 2015). One way to practice critical thinking skills is through learning chemistry on reaction rate material. In this material, students are taught to gain knowledge through data collection with literature, observation, and communication to produce explanations that can be trusted to be true. However, there are not many chemistry studies oriented towards habituation and increasing critical thinking skills in reality.

Based on these problems, one alternative learning model that can help to improve critical thinking skills in students is the guided inquiry learning model. The above statement is supported by several research results. Research findings of Fadilah \& Nasrudin (2020) indicate the application of the guided inquiry learning model gained very good criteria and students' critical thinking skills increased with the average N-gain 0.74 - 0.84 with high criteria. Rambe, Silalahi, \& Sudrajat (2020) also found that the application of guided inquiry models is effective in improving student learning outcomes and improve students' critical thinking skills. Besides, research conducted by Hikmah \& Nasrudin (2016) revealed that the implementation of guided inquiry learning models on chemical equilibrium material 
was carried out well, and students' critical thinking skills had increased with an N-Gain score of 0.75 with high criteria. The guided inquiry learning model is a learning model that emphasizes students in the process of looking for and finding their answers to the problem formulations made, while the teacher acts as a facilitator and guide for students to actively learn (Sanjaya, 2014). Through this learning model, students are expected to solve problems both in science and everyday life with their critical thinking.

The guided inquiry learning model is part of learning activities with a contextual approach. Students are expected to gain knowledge and skills from remembering facts and finding their solutions to problems through critical and analytical thinking processes (Sanjaya, 2014). Blended learning is in the form of face-to-face learning and online learning that can increase students' activities (Irawan, Sutadji, \& Widyanti, 2017). One learning model that is suitable to be combined with blended learning is the guided inquiry model consisting of phase 1 confrontation with problems, phase 2 data collection, and verification, phase 3 experimental data collection, phase 4 organizing and formulating explanations, phase 5 analyzing the inquiry process (Joyce, Weil, \& Calhoun, 2011). Herdiyana's research results that guided inquiry-based on blended learning is more effective and practical to train students' critical thinking skills (Herdiyani, 2017). The purpose of this research was to examine the effectiveness guided inquiry learning model based on blended learning on reaction rate material to improve students' critical thinking skills.

\section{METHOD}

This research used a pre-experimental research design with a One Group Pre-test Post-test design. This research was conducted at SMAN 1 Kalitidu Bojonegoro in October 2020. The research subject was all students of class XI IPA 1, totaling 36 people.

This research's learning media are the syllabus, lesson plans, and student worksheets that are adjusted to the guided inquiry model based on blended learning. Online learning activities using Google Classroom and Google Meet. While the research instruments are in the form of learning implementation observation sheets, student activity observation sheets, critical thinking skills test questions using a google form, and student response questionnaires using google form. This research's learning tools were previously validated for use in research data collection, with an average assessment score of $84.13 \%$.

This research's data collection methods are observation, tests, and student response questionnaires. Observation methods to collect data on the implementation of learning and student activities. Test method to collect critical thinking skills data. The test was conducted two times, namely the initial test before learning (pretest) and the final test after learning (posttest), using questions by the indicators of critical thinking on the sub-material of the factors that affect the reaction rate. While the student response questionnaire to find out and obtain data on student responses to guided inquiry learning models based on blended learning.

The data analysis techniques used in the research were as follows:

1. Analysis of the Implementation of the Guided Inquiry Learning Model Based on Blended Learning

The analysis was carried out based on the quality of the guided inquiry learning model's syntax implementation based on blended learning using scoring criteria. The score obtained is converted into a percentage of each syntax stage implementation using the following formula.

$$
\% \text { Implementation }=\frac{\sum \text { scores of learning steps obtained }}{\sum \text { Maximum learning step score }} \times 100 \%
$$

(Riduwan, 2011)

The value obtained is then converted into table 1 . 


\section{Jurnal Penelitian Ilmu Pendidikan, 14 (1), 2021 - 56 \\ Saekawati \& Nasrudin}

Table 1. Implementation Quality Criteria

\begin{tabular}{cc}
\hline Percentage $(\%)$ & Criteria \\
\hline $81-100$ & Very Good \\
$61-80$ & Good \\
$41-60$ & Pretty Good \\
$21-40$ & Not Good \\
$0-20$ & Not Very Good \\
\hline
\end{tabular}

2. Analysis of Student Activity

(Riduwan, 2011)

The activities of students that were observed were the activities of students during the guided inquiry learning model based on blended learning every 2 minutes for 90 minutes. The data obtained were analyzed using the formula:

$$
\% \text { activity }=\frac{\sum \text { Activities of students that appear }}{\sum \text { Overall activity }} \times 100 \%
$$

(Riduwan, 2011)

\section{Analysis of Students' Critical Skills}

The critical thinking skills can be known by using the Normalized Gain calculation, namely the following formula:

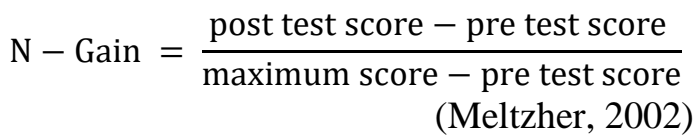

The N-Gain value scale used to interpret the critical thinking skills of the student is shown in table 2 .

Table 2. Criteria Normalized Gain

\begin{tabular}{cc}
\hline Score N-Gain & Criteria N-Gain \\
\hline $\mathrm{N}-$ Gain $>0,70$ & High \\
$0,30<\mathrm{N}-$ Gain $\leq 0,70$ & Medium \\
$\mathrm{N}-$ Gain $\leq 0,30$ & Low \\
\hline
\end{tabular}

(Meltzher, 2002)

The results of the N-Gain value were tested for normality by using the static parametric test using SPSS. The normality test in this research used the Shapiro Wilk Test. While the homogeneity test used Levene's test at the level of $\alpha=0.05$. Significant test using the t-test (Paired sample t-test), where $\mathrm{H}_{0}$ is accepted, the Asymp.Sig. (2-tailed) $<0.05$.

\section{Student Response Analysis}

Each student's response data is obtained from the acquisition of response questionnaires that have been given via google form after the learning process. The students' responses were analyzed using the Guttman scale, as shown in Table 3.

Table 3. Guttman Scale Criteria

\begin{tabular}{cc}
\hline Answer & Criteria N-Gain \\
\hline Yes & 1 \\
No & 0 \\
\hline
\end{tabular}

(Riduwan, 2011)

The calculation of the percentage of respondents' answers is calculated using the formula:

$$
\% \text { Response }=\frac{\sum \text { Answer Yes }}{\sum \text { Respondents }} \times 100 \%
$$

(Riduwan, 2011)

The response criteria of students are converted to the categories in table 4 . 


\section{Jurnal Penelitian Ilmu Pendidikan, 14 (1), 2021 - 57 \\ Saekawati \& Nasrudin}

Table 4. Student Response Criteria

\begin{tabular}{cc}
\hline Percentage $(\%)$ & Criteria \\
\hline $81-100$ & Very Good \\
$61-80$ & Good \\
$41-60$ & Pretty Good \\
$21-40$ & Not Good \\
$0-20$ & Not Very Good \\
\hline & (Riduwan, 2011)
\end{tabular}

\section{RESULT AND DISCUSSION}

\section{Results}

\section{The Implementation of Guided Inquiry Learning Model Based on Blended Learning}

The learning process is carried out using a guided inquiry learning model based on blended learning. Learning activities are divided into three parts, an introduction, a core, and a closing section. In preliminary activities, namely focusing the attention of students and explaining the inquiry process. The teacher's role in this activity is as a motivator in learning (Wikandari, 2008). The core part consists of phase 1 is the confrontation with problems, phase 2 is data collection and verification, phase 3 is collecting experimental data, phase 4 is organizing and formulating explanations, phase 5 analyzing the inquiry process (Joyce et al., 2011). And the closing activity is to give awards to students who are active in learning.

Learning is carried out following the learning implementation plan that has been prepared. Based on the syllabus and lesson plans on the sub material, the factors that influence the rate of reaction have two meetings. At the beginning of the learning activity, the teacher opens the lesson, asks how students are, and checks students' attendance. The teacher gives students an apperception by linking the material with their initial knowledge of the previous material. The teacher also motivates by observing the phenomena in the picture. Students are allowed to ask questions about the phenomenon that is displayed. The teacher conveys the learning objectives to be achieved related to the factors that affect the rate of reaction at each meeting. After the preliminary activities are completed, learning continues in the core section. The core activities are carried out according to the syntax of guided inquiry. Table 5 is an overview of the guided inquiry learning model.

Table 5. Syntax of Guided Inquiry Learning Model

\begin{tabular}{ll}
\multicolumn{1}{c}{$\begin{array}{l}\text { Guided Inquiry Learning } \\
\text { Syntax }\end{array}$} & \multicolumn{1}{c}{ Learning Activities } \\
\hline $\begin{array}{l}\text { Phase 1 (Confrontation } \\
\text { with Problems) }\end{array}$ & $\begin{array}{l}\text { Through online learning using the google meet application, students are asked by the teacher to read the } \\
\text { phenomena presented in the worksheet. The phenomena presented are related to everyday life. The teacher } \\
\text { asks students to express their opinions about identifying problems with this phenomenon. Students } \\
\text { formulate problems based on existing phenomena with teacher guidance. Students in formulation } \\
\text { activities have been trained in critical thinking skills, namely the component of interpretation. }\end{array}$
\end{tabular}

Phase 2 (Data Collection and Verification)

Phase 3 (Experimental Data Collection)

Phase 4 (Organizing and Formulating Explanations)
In online learning using google meet the teacher guides students to propose hypotheses that are following the formulation of the problem that has been made. Students in developing hypotheses are trained in critical thinking skills, namely the inference component. The teacher guides the students to determine the experimental variables that are by the experiment. Students in determining experimental variables are trained in critical thinking skills in the interpretation component.

The teacher displays an experimental video about the factors that affect the reaction rate through google meet. The teacher guides students to observe the results of the experiment and process data by making observation tables.

Through google meet, the teacher guides students to analyze observational data from the experiment results to find answers to the problem formulations that have been made. Students have trained in critical thinking skills in the analysis component that students answer and complete questions on the student worksheet's data analysis questions.

Furthermore, students are guided by the teacher to make conclusions based on the results of experimental data analysis to find concepts about the factors that affect the reaction rate. Students in making conclusions are trained in critical thinking skills, namely the inference component. The teacher asks students to connect the concepts associated with the collision theory. In this activity, students are trained in critical thinking skills, namely the explanatory component. The teacher asks students to present the discussion results in front of the class through face-to-face learning. 
Through face-to-face learning in the classroom, the teacher asks the relationship between the conclusions that students have made with the phenomenon. Then the students answered that the conclusions were made regarding the phenomena in the previous worksheet. The teacher also asks the relationship between the conclusions that students have made with the hypothesis whether it can be accepted or rejected.

At the end of learning, the teacher rewards students who are active in learning. The teacher provides information about the material studied at the next meeting. Then the teacher asks students to pray together to end the lesson. The teacher closes the lesson by saying a closing greeting. The research data results on the percentage of the implementation of guided inquiry learning based on blended learning are shown in Figure 1 below.

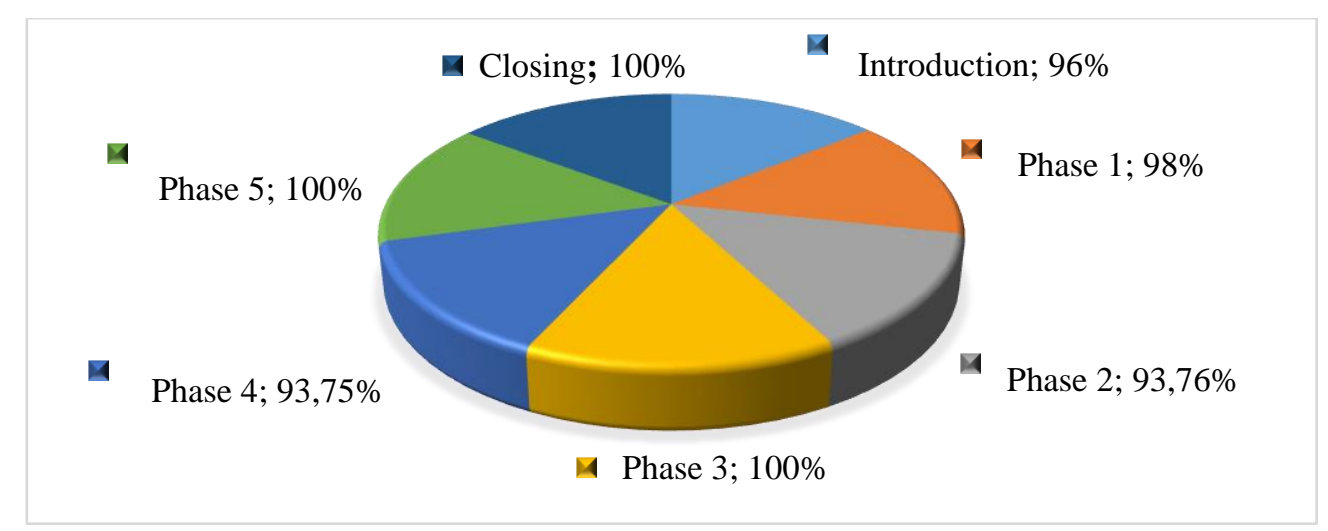

Figure 1. Percentage of guided inquiry learning implementation based on blended learning

Figure 1 shows that the percentage of learning implementation in each activity and phase is more than $61 \%$. These results explain that the guided inquiry-learning model based on blended learning is carried out very well (Riduwan, 2011). A guided inquiry learning model based on blended learning has been implemented well so that critical thinking skills can be trained. These results are supported by previous research that the process of training critical thinking skills can be done by applying syntax in the inquiry-learning model because students can find concepts independently by increasing their learning activities (Cahyani \& Azizah, 2019).

\section{Student Activity}

Students' activities during online learning are observing phenomena, determining problem formulations, and experimental variables that include interpretation indicators on critical thinking skills. Then perform data analysis, which can practice critical thinking skills on the analysis indicator. And then make hypotheses and conclusions that include inference indicators of critical thinking skills. Also, prove the result or concept according to the theory, which can train explanatory indicators on critical thinking skills. And watching a video about an experiment on the factors affecting the reaction rate to obtain experimental data.

While the activities of students during face-to-face learning, namely the presentation of the results of the discussion answering the student worksheet given by the teacher. The average percentage of student activity results can be shown in table 6 .

Based on the data in table 6 , students' activities in guided inquiry learning based on blended learning indicate that students carry out relevant activities where students have trained in critical thinking skills. These results indicate that the students' activities can be said to support the effectiveness of the implementation of the guided inquiry model to practice critical thinking skills because the percentage of relevant activities is greater than irrelevant activities. 
Jurnal Penelitian Ilmu Pendidikan, 14 (1), 2021 - 59

Saekawati \& Nasrudin

Table 6. The Average Percentage of Student Activity

\begin{tabular}{lc}
\hline \multicolumn{1}{c}{ Student activities } & Average percentage (\%) \\
\hline Students ask the teacher & 3,2 \\
Observing the phenomena in the worksheet on the Powerpoint given by the & 6,25 \\
teacher & 5,1 \\
Students make problem formulations in the worksheet (Interpretation) & 4,58 \\
Students formulate hypotheses on the worksheet (Inference) & 6,53 \\
Students determine variables in the worksheet (Interpretation) & 26,39 \\
Students observe the experimental video & 9,17 \\
Students write down their observations on a worksheet & 5,98 \\
Students perform data analysis of experimental results on the worksheet & 6,11 \\
(Analysis) & 8,89 \\
Students make experimental conclusions on the worksheet (Inference) & 8,06 \\
Students adjust the results of the experiment with the hypothesis associated with & \\
the collision theory in the worksheet (explanation) & 7,09 \\
Students express opinions / present the results of the discussion in front of the & 1,81 \\
class & 98,19 \\
Students respond to the results of presentations delivered by students & \\
Doing other irrelevant activities (joking, playing with cellphones and being \\
sleepy, etc.)
\end{tabular}

\section{Students' Critical Thinking Skills}

The data on the results of students' critical thinking skills included the pretest and posttest scores. The pretest results are used to measure students' critical thinking skills before the research is carried out. Meanwhile, the purpose of giving post-test questions is to know the critical thinking skills of students after the implementation of the guided inquiry learning model based on blended learning.

Pretest and posttest questions that contain questions about a phenomenon, then the student can identify the phenomenon by making problem formulations, formulating hypotheses, determining experimental variables, writing experimental results in tables, analyzing the experimental data, making conclusions, and explaining the results of conclusions with theory.

Students in this research were trained in critical thinking skills proposed by Facione. Critical thinking skills that are trained are only four components, namely interpretation, inference, analysis, and explanation (Facione, 2011).

Students are trained in the interpretation component by making problem formulations and determining experimental variables. One of the students' pretest answers in formulating the problem can be shown in Figure 2 below.

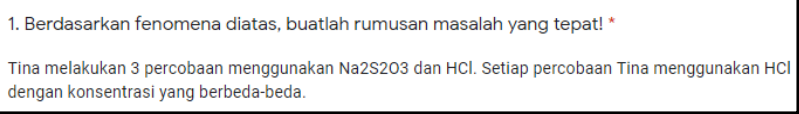

Figure 2. Pretest answers to the interpretation component below.

The students' posttest results in making the problem formulation are presented in Figure 3

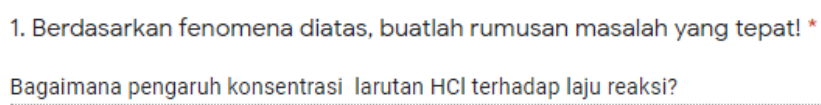

Figure 3. Posttest answers to the interpretation component

Students are trained in the analysis component when answering data analysis questions in the worksheets after conducting experiments. Examples of pretest answers from students in answering data analysis questions are shown in Figure 4 below. 
4. Perhatikan hasil pengamatan dalam tabel dibawah ini! Analisislah hasil percobaan dengan menjawab pertanyaan beriku: a. Apa yang dihasilkan oleh larutan $\mathrm{Na} 2 \mathrm{~S} 2 \mathrm{O} 3$ ketika ditambahkan pada larutan $\mathrm{HCl}$ ? b. Apakah yang menyebabkan waktu yang dibutuhkan untuk hingga tanda silang pada kertas tidak terlihat berbeda? c. Tuliskan reaksi yang terjadi pada percobaan tersebut! *

\begin{tabular}{|c|c|c|}
\hline Gelas kimia & Suhu $\left({ }^{\circ} \mathrm{C}\right)$ & Waktu (s) \\
\hline A & 30 & 13 \\
\hline B & 40 & 7 \\
\hline $\mathrm{C}$ & 70 & 2 \\
\hline
\end{tabular}

Figure 4. Pretest answers to the analysis component 5 below.

The posttest answers of students in answering data analysis questions can be presented in Figure

$$
\begin{aligned}
& \text { 4. Perhatikan hasil pengamatan dalam tabel dibawah ini! Analisislah hasil percobaan dengan } \\
& \text { menjawab pertanyaan beriku: a. Apa yang dihasilkan oleh larutan } \mathrm{Na} 2 \mathrm{~S} 2 \mathrm{O} 3 \text { ketika ditambahkan } \\
& \text { pada larutan } \mathrm{HCl} \text { ? b. Apakah yang menyebabkan waktu yang dibutuhkan untuk hingga tanda silang } \\
& \text { pada kertas tidak terlihat berbeda? c. Tuliskan reaksi yang terjadi pada percobaan tersebut! * }
\end{aligned}
$$

\begin{tabular}{|c|c|c|}
\hline Gelas kimia & Suhu $\left({ }^{\circ} \mathrm{C}\right)$ & Waktu $(\mathrm{s})$ \\
\hline $\mathrm{A}$ & 30 & 13 \\
\hline $\mathrm{B}$ & 40 & 7 \\
\hline $\mathrm{C}$ & 70 & 2 \\
\hline
\end{tabular}

Figure 5. Posttest answers to the analysis component

The inference component is trained when students formulate hypotheses and make conclusions. One of the students' pretest answers in compiling a hypothesis is presented in Figure 6 below.

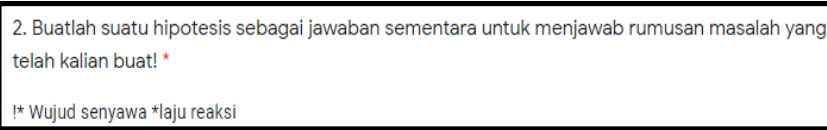

Figure 6. Pretest answers to the inference component

And the following is an example of students' posttest results in compiling a hypothesis shown in Figure 7 below.

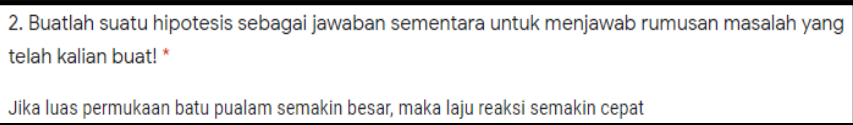

Figure 7. Posttest answers to the inference component

Students are trained in the explanatory component by answering student worksheet questions regarding the relationship between the reaction rate factor and the collision theory. Examples of pretest answers from students in answering explanatory questions are shown in Figure 8 below.

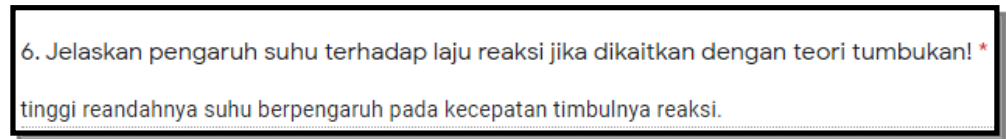

Figure 8. Pretest answers to the explanation component

After being trained in critical thinking skills, students are given posttest questions to know the extent to which they understand the explanatory components. Examples of students' posttest answers in answering the explanatory component questions can be presented in Figure 9 below. 
6. Jelaskan pengaruh suhu terhadap laju reaksi jika dikaitkan dengan teori tumbukan! *

Semakin besar suhu yang digunakan saat bereaksi, maka energi kinetik partikel pereaksi akan semakin besar yang menyebabkan tumbukan efektif semakin sering terjadi, sehingga laju reaksi semakin besar

Figure 9. Posttest answers to the explanation component

The N-Gain test is used to find out how much critical thinking skills increase students have after being given a guided inquiry learning model based on blended learning. Students can be declared to have increased if the $\mathrm{N}$-gain score obtained reaches the criteria for medium $(0.3 \leq \mathrm{g}<0.7)$ or high ( $\mathrm{g}$ $\geq 0.7$ ). Learning can be said to be effective if the $\mathrm{N}$-gain value is included in the medium or high criteria. The results of the pretest and posttest recapitulation can be seen in table 7 .

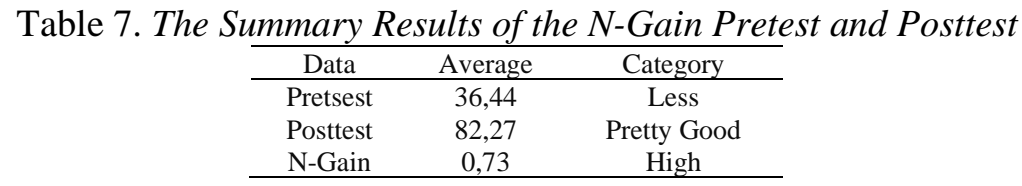

Based on the results of the processed data, as shown in table 7, the average posttest score with the very high category is higher than the average pretest score with the less category. This shows that after being given a guided inquiry learning model based on blended learning, students' critical thinking skills increase. And they were supported by an average N-Gain of 0.73 with a high category, which proves that the learning model used is effective.

The average N-Gain results on each component of critical thinking skills consisting of components of interpretation, analysis, inference, and explanation with different categories are shown in Figure 10.

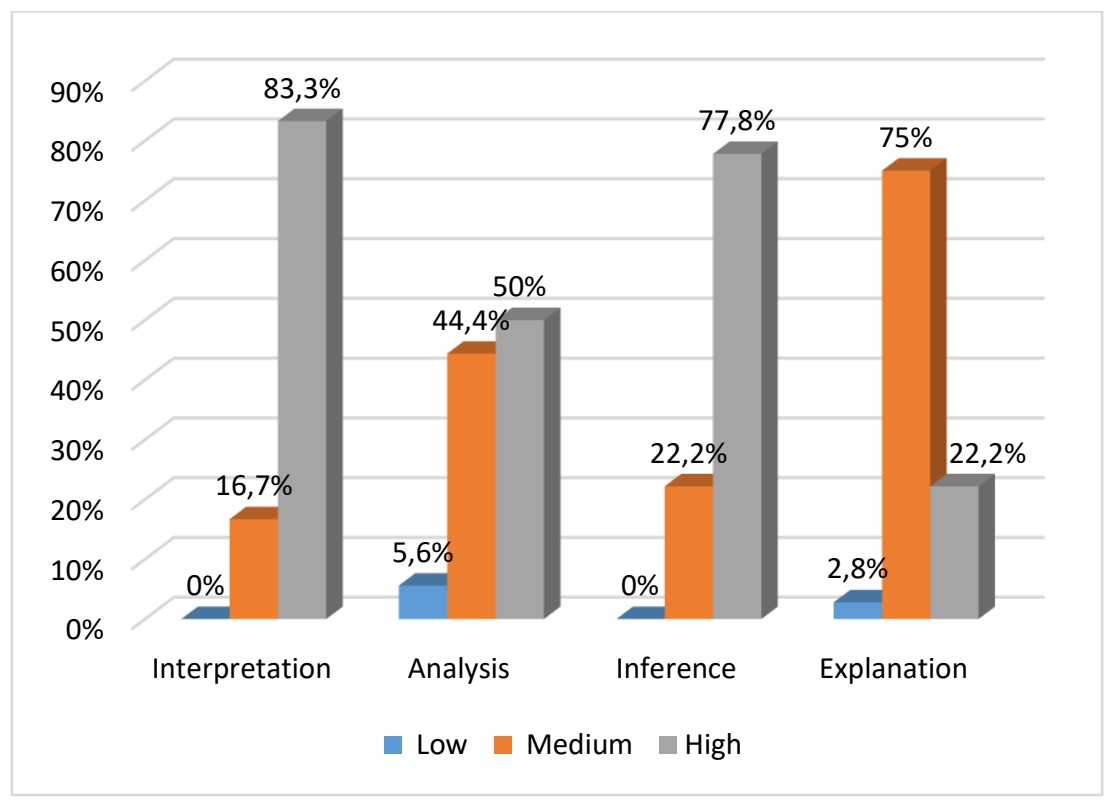

Figure 10. The average N-Gain in each component of critical thinking skills

It was then tested for normality and homogeneity of data as a prerequisite for testing the hypothesis. The normality test was tested on the pretest and posttest data to find out whether the data were normally distributed or not. Therefore, it can determine the statistical analysis used in parametric statistics (normal data) or non-parametric (abnormal data). The normality test was performed using the Shapiro-Wilk test at the significance level $\alpha=0.05$. The results of the Shapiro-Wilk pretest-posttest normality test is in table 8 . 
Jurnal Penelitian Ilmu Pendidikan, 14 (1), 2021 - 62

Saekawati \& Nasrudin

Table 8. Shapiro Wilk Normality Test Results

\begin{tabular}{ccccc}
\hline \multirow{2}{*}{ Data } & \multicolumn{3}{c}{ Shapiro-Wilk } & \multirow{2}{*}{ Information } \\
\cline { 2 - 4 } & Statistic & df & Sig. & \\
\hline Pre-Test & .971 & 36 & .458 & Normal \\
Post-Test & .945 & 36 & .072 & Normal \\
\hline
\end{tabular}

Based on the results of the normality test in table 8, a significant value for the pretest is 0.458 and a significant value for the posttest is 0.072 . The two significant values are more than $\alpha$ (sig.> 0.05). Therefore, it can conclude that the pretest and posttest value data are normally distributed.

Furthermore, the homogeneity test has done to see whether the pretest and posttest data came from homogeneous variances to compare the data. Homogeneity test has done using Levene's test. The following are the results of the pretest-posttest homogeneity test (Shapiro-Wilk) in table 9.

Table 9. Homogeneity Test of Pretest-Posttest

\begin{tabular}{cccccc}
\hline Based on & Levene Statistic & $d f 1$ & $d f 2$ & Sig. & Information \\
\hline Mean & 1.959 & 1 & 70 & .166 & Homogen \\
Median & 1.839 & 1 & 70 & .1 .79 & Homogen \\
Median and with & 1.839 & 1 & 69.714 & .179 & Homogen \\
adjusted df & 1.897 & 1 & 70 & .173 & Homogen \\
Trimmed mean & &
\end{tabular}

Based on the results of the Levene's test, it is known that the pretest and posttest data based on the mean, median, median and with adjusted df, and trimmed shows that the significance value is greater than $\alpha$ (sig.> 0.05) so it can be concluded that the two data groups have the same variance called homogeneously.

Based on the sample used normally distributed and homogeneous, the Independent Sample Ttest was conducted to determine whether there was a significant difference in the results of critical thinking skills between before and after being given a guided inquiry learning model based on blended learning. The results of the Independent Sample t-test are in table 10.

Table 10. T Test Result for Pretest and Posttest

\begin{tabular}{cccc}
\hline & $\mathrm{t}$ & $\mathrm{df}$ & Sig. (2-tailed) \\
\hline Pretsest -Posttest & 27.939 & 35 & .000 \\
\hline
\end{tabular}

Based on the results of the Independent Sample t-test, a significance value (sig.) is 0,000 . When compared with the fundamental level $(\alpha-0.005)$, it shows that the significance value is smaller than $\alpha$ $(0.000<0.05)$ so it can be said that $\mathrm{H}_{0}$ is rejected. Therefore, it can conclude that there is a significant difference in critical thinking skills between before and after had given a guided inquiry-learning model based on blended learning. This is following the hypothesis that had given.

\section{Student Response}

The following describes the student response questionnaire in detail in each aspect of the statement contained in Table 11.

Table 11. Student Response Questionnaire

\begin{tabular}{|c|c|c|c|c|c|}
\hline \multirow[t]{2}{*}{ Questions } & \multicolumn{2}{|c|}{ Number of Opinions } & \multicolumn{2}{|c|}{ Percentage $(\%)$} & \multirow[t]{2}{*}{ Criteria } \\
\hline & Yes & No & Yes & No & \\
\hline $\begin{array}{l}\text { Do you like learning using a guided inquiry learning model } \\
\text { based on blended learning on reaction rate material? }\end{array}$ & 36 & 0 & 100 & 0 & Very good \\
\hline $\begin{array}{l}\text { Do you find it easier to understand the reaction rate material } \\
\text { with the application of the guided inquiry learning model } \\
\text { based on blended learning? }\end{array}$ & 32 & 4 & 89 & 11,11 & Very good \\
\hline $\begin{array}{l}\text { Can the guided inquiry learning model based on blended } \\
\text { learning train your critical thinking skills? }\end{array}$ & 36 & 0 & 100 & 0,00 & Very good \\
\hline $\begin{array}{l}\text { Does the blended learning-based guide inquiry learning } \\
\text { model help you to be active in learning? }\end{array}$ & 32 & 4 & 89 & 11,11 & Very good \\
\hline $\begin{array}{l}\text { Does the blended learning-based guide inquiry learning } \\
\text { model help you relate the material to phenomena that occur } \\
\text { in everyday life? }\end{array}$ & 33 & 3 & 92 & 8,33 & Very good \\
\hline
\end{tabular}




\begin{tabular}{l}
$\begin{array}{l}\text { Do you find it easier to learn with a model guided inquiry } \\
\text { learning based on blended learning? }\end{array}$ \\
$\begin{array}{l}\text { Do you want the blended learning-based guided inquiry } \\
\text { learning model to be applied to other subject matter? }\end{array}$ \\
\hline Average
\end{tabular}

Table 11 shows that the percentage of students who answered "Yes" or the percentage of positive responses, which is $92 \%$ and the result is $\geq 61 \%$ so that it can be assumed that all students agree. The blended learning-based guided inquiry model effectively uses student learning activities to practice critical thinking skills on the reaction rate material.

\section{Discussion}

\section{The Implementation of Guided Inquiry Learning Model Based on Blended Learning}

To improve critical thinking skills in this study was carried out training critical thinking skills using a guided inquiry learning model based on blended learning. Learning activities are carried out face-to-face and online. Online learning provided in this study is through google classroom. Students can enter the online class group through the code provided by the teacher, with each student having a google mail account. In the online class group on google classroom, a google meet link is provided for online learning activities. Through google classroom, students can download subject matter in the form of powerpoints, student worksheets, experiment videos, and online discussions regarding sub-material factors that affect the reaction rate. All teaching materials that have been uploaded will be stored automatically on google drive so that students do not need to save soft files of teaching materials manually.

The finding of this research shows that the percentage of learning implementation in each activity and phase is more than $61 \%$ or having good criteria. This means that Inquiry learning can be used to train students' critical thinking skills. The results are following the research of Firdausichuuriyah \& Nasrudin (2017) which shows the average percentage of learning implementation in the first meeting was obtained $96.43 \%$, and the second meeting was obtained $97.62 \%$, which is more than $61 \%$ in a very good category. The application of learning based on blended learning has been able to make students more motivated in exploring subject matter through reading and learning videos. The guided inquiry learning model based on blended learning also has been made it easier for students to understand the subject matter of reaction rate material that requires deep understanding. It provides convenience in the learning process inside and outside the classroom.

With online learning, students can have the freedom of learning because they can learn wherever and whenever. However, the success of online learning is also determined by how students participate in it. Education is carried out as an effort to foster the good personalities of students. The finding of this research is also following the opinion which states that in education, the implementation of learning can take place faceto-face in the classroom, or online by utilizing the internet network (Intania \& Sutama, 2020). According to Sriarunrasmee, Wawta \& Rattiya (2015), the advantage of using the internet in learning is that students can access broader and deeper knowledge and provide new experiences to create a pleasant learning atmosphere.

Offline or face-to-face learning in class is in the form of a presentation of the results of student worksheet discussions, discussions between groups, and questions and answers regarding the results of student worksheet discussions. Learning activities carried out in this study are following the results of Fuad's research (2020) that students' critical thinking skills can be influenced by the method of discussion. That means through social interaction students can improve critical thinking skills in students. Students' activities in collaborative group work also provide opportunities for them to work together in planning, implementing, negotiating, and evaluating when completing assignments or problems given by the teacher (Fung, 2017).

\section{Student Activity}

Based on the results of data processing, students' activities are to be said to support the effectiveness of implementing the guided inquiry model based on blended learning to practice critical thinking skills in table 6 . These results indicate that the percentage of relevant activities is greater than in irrelevant activities. 
The guided inquiry learning model provides opportunities for students to discuss to search and find their answers from the formulation of problems made so that it is expected to foster a confident attitude and play an active role in students. The guided inquiry learning model is a model that allows students to can identifying problems, formulating problems, hypotheses, collecting data, verifying results, and drawing conclusions (Matthew \& Igharo, 2013). Regarding blended learning, Gastelu, Dominguez, Garcia, Kiss \& Espinoza (2015) argue that even though they have just been present in class, the use of information technology as a learning medium has opened the way for a transformation in the selection of models or methods used by educators so that students become more active.

Through the phenomena in the worksheet as initial problem identification and make problem formulation related to the material, this activity guides students in carrying out concept construction activities in groups. This student interaction is a means of practice critical thinking skills in the learning process. According to DeWaelsche (2015), asking questions can initiate the process of students thinking skills. The students' ability to ask critical questions is also one of the skills that are expected to be acquired in the 21 st century. Student activities in this research are also following the research findings of Duran \& Dokme (2016), the activity of answering and asking questions contributes positively to the development of a level of critical thinking. Discussions can also increase the level of critical thinking of students and help students improve their ability to connect between claims and evidence. Likewise, Ryan (2015) teaches critical thinking skills by allowing students to play an active role by asking questions and challenges so that students are motivated.

The observation also shows that almost all students are actively involved in solving contextual problems through investigative activities. Students criticize the problems they faced, develop plans, and carry out problem-solving. This reinforces the research results of Rusilowati \& Khanafiyah (2012) that open investigation can improve students' critical thinking skills.

\section{Students' Critical Thinking Skills}

The interpretation component is trained through phase 1 in the syntax of the guided inquiry learning model by answering the questions in the student worksheet about making problem formulations based on the given phenomena. Also, the interpretation component is trained in phase 2 on the syntax of the guided inquiry model by answering questions about identifying experimental variables. The interpretation components were tested using pretest and posttest. At the time of the pretest, it seemed that students could not formulate problems. Students have not met the indicators of good and correct problem formulations, where students have not formulated the problem in the form of questions, are not following the phenomenon, and do not consist of two interrelated variables so that students get a score of 1. At the time of the posttest, the students appeared to write the correct answers in making the problem formulation. Students make problem formulations following the indicators of good and correct problem formulations so that students get a score of 4 . The score shows that students can make good and correct problem formulations and can identify situations or events to other forms of representation, namely the formulation of the problem.

Students can interpret information using relevant data or information. Students can assess statements logically and accurately so that students can determine the information that is following the description. Critical thinking skill is a person's ability to analyze an idea using logical reasoning. This is in line with what is expressed by Yasushi (2016), critical thinking is the set of skills and dispositions which enable one to solve problems logically and to attempt to reflect autonomously using metacognitive regulation on one's problem-solving processes.

The analysis component is trained through phase 4 in the guided inquiry learning model syntax by answering questions about the analysis of experimental results and tested using pretest and posttest. Based on the pretest, students have not been able to answer data analysis questions. Students have not fulfilled the indicators of good and correct data analysis, where students have not answered questions of data analysis following the phenomenon, are related to existing theories, and write down the reactions that occur. The mismatch between students' answers and the correct data analysis indicators causes students to get low scores. Students in the learning process are trained by the teacher in solving data analysis questions so that students can identify the relationship between the statements obtained from the results of the experiment with the questions is in the student worksheet. In the posttest, it can be seen that students in writing answers to analysis questions have progressed when compared to the 
pretest. The suitability between the answers written by students with the data analysis indicator causes students to get a maximum score of 4 . The increase in categories at the time of the posttest is because students can link the suitability of the questions and arguments. In analyzing arguments because students already understand the meaning of the questions given by considering decision making.

Critical thinking skills can also be interpreted as a person's ability to think about making decisions. As stated by Patricia (2010: 197) "Less formal and more skeptical definition of critical thinking: deciding what to do and when, where, why, and how to do it". The same thing was also expressed (Facione, Giancarlo, Facione, \& Gainen, 2015) said that critical thinking is a process of making reasoned judgments based on the consideration of available evidence, contextual aspects of a situation, and pertinent concepts. Based on the expert's explanation, it can be concluded that critical thinking skill is the ability to think logically, reflectively, systematically, and productively which is applied in making good considerations and making good decisions.

The inference component is trained through the application of phase 2 in the syntax of the guided inquiry learning model by answering questions about making hypotheses, as well as by answering questions about graphing the relationship between factors and reaction rates. Besides that, the inference component is also trained in phase 4 in the guided inquiry learning model's syntax, which is to make conclusions based on the experimental results. At the pretest, students wrote inaccurate answers in making hypotheses. Students have not met the right hypothesis indicators, where students write hypotheses that are not following the phenomenon and do not consist of two related variables so that students get a score of 3 . The score is obtained because students answered by including only one hypothesis indicator. Students experience an increase in the inference component after the blended learning-based guided inquiry learning model is applied. Based on the posttest, students write the right hypothesis, this is because the hypothesis written by students meets the hypothesis indicators that are good and true. This indicator proves that all students are skilled in deciding the truth in considering statements based on the information contained in the description. This shows that students have been trained in the inference component.

In the inference component, students are trained in making assumptions by being allowed to make decisions using relevant and logical data. Students who can make conclusions are very skilled because they answer thoughtfully and relate to the right information. The correct conclusions must be based on the steps of logical conclusion reasons and students can write the conclusion correctly (Ennis, 1995). This is following the opinion of Browne \& Stuart, (2015:32), that critical thinkers must be able to find "what the writer wants to prove?" or "what are the main points the communicator wants to convey?". Likewise, Fisher, (2007:106) states that "a critical thinker starts one or more beliefs, from these beliefs to other beliefs that they take to be justified by the initial beliefs to conclude".

The explanation component is trained through the application of phase 4 in the syntax of the guided inquiry learning model by answering questions about explaining the factors that affect the reaction rate using collision theory. In the pretest, it appears that students have not been able to answer questions about the explanation component. Students have not met the explanatory indicators that are good and correct, where students have not answered questions that consist of two related variables, linking the relationship between the reaction rate factor and the activation energy, explaining the relationship with the number of collisions. The mismatch between students' answers and the correct data analysis indicators causes students to get low scores. Students in the learning process are trained by the teacher in solving explanatory questions so that students can explain the factors that affect the reaction rate associated with the collision theory. At the time of the posttest, it was known that students in writing answers to the explanatory component questions during the posttest had progressed when compared to the pretest. The suitability between the answers written by students with the data explanation indicator causes students to obtain a maximum score of 4 . The score shows that students have been trained in the explanation component.

This indicator proves that students are already skilled in deciding the truth in considering statements based on the information contained in the description. Following Facione (2011), the explanation is the ability to state the results of thoughts, explanation of reasons based on consideration of evidence, methodological concepts, criteria, and context.

Table 7 shows that students obtained an average N-Gain score with a high category based on the data. It can be said that critical thinking skills have been successfully trained and increased. This 


\section{Jurnal Penelitian Ilmu Pendidikan, 14 (1), 2021 - 66 \\ Saekawati \& Nasrudin}

finding is in line with Hikmah \& Nasrudin's (2016) 's research that critical thinking skills have increased from before and after learning through the implementation of guided inquiry learning models on chemical equilibrium material with high criteria of $\mathrm{N}$-gain score. This finding also reinforces the research result of (Rambe et al., 2020) that the application of guided inquiry models is effective in improving student learning outcomes and improve students' critical thinking skills. With blended learning, the findings of this study are following some research, namely, Ramdani \& Badriah (2018) argue that there is a relationship between critical thinking skills and learning outcomes due to the suitability of a guided inquiry model based on blended learning that focuses on authentic problems that are ill-structured, it can improve critical thinking skills. This is supported by research conducted by Zain \& Jumadi (2018) that the guided inquiry learning model carried out by blended learning was able to improve students' critical thinking skills.

Based on the results of the significance test using the t-test, the conclusion that the hypothesis can be obtained is that $\mathrm{H}_{0}$ is rejected. To see the results of t-test data processing are shown in table 10 . This indicates that there is a significant difference in the results of critical thinking skills between before and after being given the guided inquiry learning model based on blended learning.

\section{Student Response}

Student response is students' impression or opinion on the guided inquiry learning model based on blended learning. Student responses can be used to find out the advantages and disadvantages of the learning model based on the students' point of view. Besides that, the teacher's introspection is used on the learning model applied in the future.

The data in table 11 shows that the results of students' responses to each question obtained a positive response that was greater than the negative response. The average percentage of idealized student responses who answered positively to the blended-based guided inquiry learning model was $92 \%$ with a very good category. Based on these results, it can be concluded that the teacher has successfully applied the guided inquiry learning model based on blended learning to practice and improve critical thinking skills on the reaction rate material. This result is following the research of Hikmah \& Nasrudin (2016) which revealed that students' responses through the implementation of guided inquiry learning models on equilibrium chemistry were very good category. Likewise finding the research Rizal (2014), students like the guided inquiry learning method because students are allowed to know and are actively involved in discovering concepts from existing phenomena from the environment with the guidance of the teacher.

\section{CONCLUSION}

Based on the results of research and discussion, it can be concluded that critical thinking skills that are trained by applying a guided inquiry learning model based on blended learning on the material reaction rate are carried out in the very good category. The average value of $\mathrm{N}$-gain for critical thinking ability was a high category. There is a significant difference in the results of critical thinking skills between before and after being given a guided inquiry learning model based on blended learning. The results showed that the guided inquiry learning model based on blended learning was effective for training students' critical thinking skills, but blended learning needed to be considered. The implementation of blended learning research to improve critical thinking skills takes a long and continuous period.

\section{ACKNOWLEDGEMENT}

We would like to thank all those who have supported this research activity. The first author would like to say thank you to Dr. Sukarmin, M.Pd, as the UNESA Chemistry Education Department head. I would also like to say thank you to Prof. Dr. Harun Nasrudin, M.S. as a thesis lecturer who has provided motivation and knowledge to complete this research. I would also like to thank Siti Kustiwi, S.Pd. as a chemistry teacher at SMAN 1 Kalitidu Bojonegoro, who helped the author and permitted me to research. 
Jurnal Penelitian Ilmu Pendidikan, 14 (1), 2021 - 67

Saekawati \& Nasrudin

\section{BIBLIOGRAPHY}

Amri, S. (2015). Implementasi pembelajaran aktif dalam kurikulum 2013. Jakarta: Prestasi Pustakakarya.

Browne, M. N., \& Stuart, M. K. (2015). Pemikir kritis: Panduan untuk mengajukan dan menjawab pertanyaan kritis. Jakarta: Indeks.

Cahyani, N. I., \& Azizah, U. (2019). Penerapan model inkuiri terbimbing untuk melatihkan keterampilan berpikir kritis siswa pada materi laju reaksi kelas xi sma. UNESA Journal of Chemical Education, 8(3), 320-326.

Cano, \& Maryinez. (1991). The relationship between cognitive performance and critical thinking abilities among selected agricultural education students. Journal of Agricultural Education, 32(1), 24-29. https://doi.org/10.5032/jae.1991.01024.

DeWaelsche, S. A. (2015). Critical thinking, questioning and student engagement in Korean university English courses. Linguistics and Education, 32, 131-147.

Duran, M., \& Dokme, I. (2016). The effect of the inquiry-based learning approach on student's criticalthinking skills. Eurasia Journal of Mathematics, Science \& Technology Education, 12(12), 28872908.

Ennis, R. H. (1995). Critical thinking. New York: Prentice-Hall.

Facione, P. (2011). Critical thinking: What it is and why its counts. London: In Measured Reason and The California Academic Press.

Facione, P. A., Giancarlo, C. A., Facione, N. C., \& Gainen, J. (2015). The disposition toward critical thinking 1 by. Journal of General Education, 44(1), 1-17.

Fadilah, A., \& Nasrudin, H. (2020). Implementation of inquiry learning models integrated with nested to increase student's critical thinking skills on electrolyte and non-electrolyte solution materials. Journal of Chemistry Education Research (JCER), 4(2), 83-92.

Firdausichuuriyah, C., \& Nasrudin, H. (2017). Keterlaksanaan penerapan model pembelajaran inkuiri terbimbing untuk meningkatkan keterampilan berpikir kritis siswa materi larutan elektrolit dan non elektrolit kelas x sman 4 sidoarjo. UNESA Journal of Chemical Education, 6(2), 184-189.

Fisher, A. (2007). Berpikir kritis: Sebuah pengantar. Jakarta: Erlangga.

Fuad, A. J. (2020). Method of discussion and learning styles towards student's critical thinking ability. Jurnal Penelitian Ilmu Pendidikan, 13(1), 1-9.

Fung, D. (2017). The pedagogical impacts on students' development of critical thinking dispositions: Experience from Hong Kong secondary schools. Thinking Skills and Creativity, 26, 128-139.

Gastelú, C. A. T., Dominguez, A. L., Garcia, M. A. F., Kiss, G., \& Espinoza., A. R. A. (2015). Student's perception about online interaction, access and publishing content for academic use. TOJET, $14(3), 138-144$.

Herdiyani, F. (2017). Implementasi perangkat pembelajaran blended community of inquiri untuk melatihkan kemampuan berpikir kritis mahasiswa calon guru biologi. Seminar Nasional. Membangun Generasi Berkarakter Melalui Pembelajaran Inovatif.

Hikmah, A., \& Nasrudin, H. (2016). Implementation of guided inquiry learning model to practice critical thinking skill on chemical equilibrium material at sma negeri Probolinggo. UNESA Journal of Chemical Education, 5(1), 159-166.

Intania, E. V., \& Sutama. (2020). The role of character education in learning during the COVID-19 pandemic. Jurnal Penelitian Ilmu Pendidikan, 13(2), 129-136.

Irawan, V. T., Sutadji, E., \& Widyanti. (2017). Blended learning based on schoology: effort of improvement learning outcome and practicum chance in vocational high school. Cogent Education, 4, 1-10.

Joyce, B. R., Weil, M., \& Calhoun, E. (2011). Models of teaching (8th ed.). USA: Pearson Education Inc.

Kemendikbud. (2016). Peringkat dan capaian pisa Indonesia mengalami peningkatan. Retrieved from https://www.kemdikbud.go.id/main/blog/2016/12/peringkat-dancapaian-pisa-indonesiamengalamipeningkatan.

Matthew, B. M., \& Igharo, O. K. (2013). A study on the effects of guided inquiry teaching method on students achievement in logic. International Research, 2(1), 134-140. 
Meltzher, D. E. (2002). The relationship between mathematics preparation and conceptual learning gains in physics: A possible "hidden variable" in diagnostic pretest scores. American Journal of Physics, 70(12), 1259-1268. https://doi.org//10.1119/1.1514215.

Murti, M. (2013). Pendidikan abad 21 dan implementasinya pada pembelajaran di smk untuk paket keahlian desai interior. In Artikel Kurikulum 2013 SMK.

OECD. (2013). Results excellence and equity in education. OECD Publishing.

OECD. (2016). Results excellence and equity in education. OECD Publishing.

Patricia, C. S. (2010). Thinking critically. Journal Aorn, 91(2), 197-199.

Rambe, Y. A., Silalahi, A., \& Sudrajat, A. (2020). The effect of guided inquiry learning model and critical thinking skills on learning outcomes. Advances in Science, Education and Humanities Research. Atlantic Press., 488(1), 151-155.

Ramdani, D., \& Badriah, L. (2018). Korelasi antara kemampuan berpikir kritis dengan hasilbelajar siswa melalui model pembelajaran inkuiri terbimbing berbasis blended learning pada materi sistem respirasi manusia. Jurnal Bio Educatio, 3(2), 37-44.

Riduwan. (2011). Skala pengukuran variabel-variabel penelitian. Bandung: Alfabeta.

Rizal, M. (2014). Pengaruh pembelajaran inkuiri terbimbing dengan multi representasi terhadap keterampilan proses sains dan penguasaan konsep ipa siswa smp. Jurnal Pendidikan Sains, 2(3), $159-165$.

Rusilowati, A., \& Khanafiyah, S. (2012). Implementasi model eksperimen gelombang open-inquiry untuk mengembangkan keterampilan berpikir kritis mahasiswa fisika. Jurnal Pendidikan Fisika Indonesia, 8(1), 41-50.

Ryan, D. S. (2015). How critical is critical thinking? East Lansing: Michigan State University.

Saavedra, A. R., \& Opfer, V. D. (2012). Teaching and learning 21 st century skills: lessons from the learning sciences, a global cities education network report. Retrieved from http://asiasociety.org/files/ rand-1012report.pdf.

Sanjaya, W. (2014). Strategi pembelajaran: Berorientasi standar proses pendidikan. Jakarta: Kencana Prenada Media.

Sriarunrasmee, J., Wawta, T., \& Rattiya, P. M. (2015). Blended learning supporting self-directed learning and communication skills of srinakharinwirot university's first year students. Procedia Social and Behavioral Sciences, 197(2), 1564-1569.

TIMSS. (2015). Math student achievement infographic grade 4. Retrieved from http://timss2015.org/download-center.

Trilling, B., \& Fadel, C. (2009). 21 st century skills, learning for life in our times. New York: John Wiley $\&$ Sons.

Wikandari, P. N. (2008). Pengajaran berpusat pada siswa dan pendekatan konstruktivis dalam pengajaran. Surabaya: Unesa PSS.

Yasushi, G. (2016). development of critical thinking with metacognitive regulation. International Conference on Cognition and Exploratory Learning in Digital Age (CELDA 2016). Niigata University.

Zain, A. R., \& Jumadi. (2018). effectiveness of guided inquiry based on blended learning in physics instruction to improve critical thinking skills of the senior high school student. Journal of Physics: Conf. Series, 1-6. https://doi.org/10.1088/1742-6596/1097/1/012015. 